- The most important step in treatment planning is determining the prognosis of the remaining dentition.

- There is some evidence that placement of foreign materials into extraction sockets will interfere with normal bone formation.

- Immediate implant placement when indicated provides several advantages for both practitioner and patient.

\title{
Immediate implant placement: treatment planning and surgical steps for successful outcomes
}

\author{
W. Becker ${ }^{1}$
}

\begin{abstract}
Diagnosis and treatment planning are key factors in achieving successful outcomes after placing and restoring implants placed immediately after tooth extraction. The efficacy of immediate implant placement has been established and shown to be predictable if reasonable guidelines are followed. Some or all of the following suggestions, depending on individual circumstances, should be considered when evaluating a patient for dental implants: thorough medical and dental histories, clinical photographs, study casts, periapical and panogram radiographs as well as a linear tomography or computerised tomography of the proposed implant sites. Reasons for tooth extraction include but are not limited to: insufficient crown to root ratios, remaining root length, periodontal attachment levels, periodontal health of teeth adjacent to the proposed implant sites, unrestorable caries, root fractures with large endodontic posts, root resorption, teeth with deep furcation invasions being considered as abutments for fixed partial dentures and questionable teeth in need of endodontic retreatment.
\end{abstract}

\begin{tabular}{|l|}
\hline IMPLANTS \\
\hline 1. Rationale for dental implants \\
\hline $\begin{array}{l}\text { 2. Treatment planning of implants in } \\
\text { posterior quadrants }\end{array}$ \\
\hline $\begin{array}{l}\text { 3. Treatment planning of implants in } \\
\text { the aesthetic zone }\end{array}$ \\
\hline $\begin{array}{l}\text { 4. Surgical guidelines for dental } \\
\text { implant placement }\end{array}$ \\
\hline $\begin{array}{l}\text { 5. Immediate implant placement: } \\
\text { treatment planning and surgical } \\
\text { steps for successful outcomes }\end{array}$ \\
\hline $\begin{array}{l}\text { 6. Treatment planning of the } \\
\text { edentulous maxilla }\end{array}$ \\
\hline $\begin{array}{l}\text { 7. Treatment planning of the } \\
\text { edentulous mandible }\end{array}$ \\
\hline $\begin{array}{l}\text { 8. Impressions techniques for implant } \\
\text { dentistry }\end{array}$ \\
\hline $\begin{array}{l}\text { 9. Screw versus cemented implant } \\
\text { supported restorations }\end{array}$ \\
\hline $\begin{array}{l}\text { 10. Designing abutments for } \\
\text { cement retained implant supported } \\
\text { restorations }\end{array}$ \\
\hline 11. Connecting implants to teeth \\
\hline $\begin{array}{l}\text { 12. Transitioning a patient from teeth } \\
\text { to implants } \\
\text { contemporary treatment planning }\end{array}$ \\
\hline $\begin{array}{l}\text { 13. The role of orthodontics in implant } \\
\text { dentistry }\end{array}$ \\
\hline $\begin{array}{l}\text { 14. Interdisciplinary approach to } \\
\text { implant dentistry }\end{array}$ \\
\hline 15. Factors that affect individual \\
\hline
\end{tabular}

\section{INTRODUCTION}

Teeth requiring root amputations, hemisections or advanced periodontal procedures may have a questionable prognosis and patients should be given the implant option before these procedures are implemented. Similarly, non vital teeth, fractured at the gingival margin with roots shorter than $13 \mathrm{~mm}$, should be considered for the implant option. This review will describe the steps for immediate implant placement at the time of extraction as well as the 'gap' and socket preservation. We will also discuss the concept of minimally invasive surgery when applied to implants placed at the time of extraction.

Placement of endosseous implants has made it possible to restore patients who are fully or partially edentulous. ${ }^{1-3}$ Original protocols required placement of implants into healed edentulous ridges. Lizzara placed implants at the time of extraction. ${ }^{4}$ These implants were augmented

${ }^{1}$ Clinical Professor of Periodontics at the University of Southern California School of Dentistry, Los Angeles, California / Affiliate Professor of Periodontics at the University of Washington, Seattle, WA, 801 N. Wilmot, B2, Tucson, Arizona 85711, USA Correspondence to: Dr W. Becker

Email: branebill@comcast.net

Portions of this paper were published in the California Dental Journal $(2005 ; 33)$. Permission has been granted by CDA to use this article and photos. The article was not reproduced in its entirety.

Refereed Paper

(c) British Dental Journal 2006; 201 : 199-205

DOI: $10.1038 /$ sj.bdj.4813881 with barrier membranes to preserve ridge width and height and to decrease total treatment time. Becker et al. reported a 93.3\% implant survival rate for implants placed at the time of extraction and augmented with barrier membranes after one and five years following loading. ${ }^{5,6}$ Over the past 16 years numerous studies have confirmed the predictability of placing implants at the time of extraction. ${ }^{7-10}$ Small osseous defects are frequently found adjacent to implants placed at the time of extraction. These defects can be implanted with small autogenous grafts taken from edentulous ridges or other sites. ${ }^{11,12} \mathrm{~A}$ prospective clinical trial placed implants immediately after tooth extraction. ${ }^{11}$ Defects were grafted with small autologous bone chips harvested from adjacent edentulous ridges. One year after implant loading the survival rates were 93.3\% with clinically insignificant crestal bone loss. Others have used various materials and methods including demineralised freeze dried bone and barrier membranes to augment edentulous ridges and small defects adjacent to dental implants. ${ }^{13-23}$ The stability of the implant can be verified using resonance frequency analysis. ${ }^{24-29}$ This method requires placement of an electronic transducer onto the implant head or prosthetic abutment with a retaining screw, and passing a low voltage current through the transducer. The current is not detected by the patient. Resistance to vibration of the transducer to the surrounding bone is registered in a special small 
computer. The original research measurements were made in Hertz. Hertz measurements have been calibrated for each transducer and are converted to Implant Stability Quotient (ISQ) units by the computer. Measurements are recorded as ISQ values.

A recent study evaluated stability of implants placed at the time of extraction with resonance frequency analysis. ${ }^{30}$ Stability measurements were taken at the time of implant placement and after healing. The average interval between implant insertion and abutment connection was 5.6 months. Two implants were lost between implant insertion and one year. At two to three years the cumulative survival was $97.2 \%$. Resonance frequency measurements at implant placement showed a mean primary stability of $62.0 \pm 9.8$ ISQ and a mean secondary stability after one year of $64.0 \pm 9.8$ ISQ for all implants. The increase was not statistically significant. The primary stability in the maxilla was significantly lower than in the mandible, while no difference was seen for secondary stability. Initial average stability measurements were high. Measurements taken after healing were not significantly higher than those recorded initially. Studies indicate that implants with an RFA greater than 50 are stable. Sites which receive implants at the time of extraction or within a short time after extraction demonstrate slight decreases in crestal bone width. ${ }^{30,31}$

It is the purpose of this paper to review the concept of immediate implant placement and to expand the indications, limitations, anatomic, prosthetic and aesthetic requirements for placement of implants at the time of extraction. The concept of 'socket preservation' for sites that might receive dental implants as well as guided implant placement will be discussed. We will also introduce the idea of minimally invasive surgery and guided implant placement for implants placed at the time of extraction.

\section{Diagnosis and treatment planning}

Diagnosis and treatment planning are key factors in achieving successful outcomes after placing and restoring implants placed immediately after tooth extraction. Following some or all of the following suggestions, depending on individual circumstances, should be considered when evaluating a patient for dental implants: thorough medical and dental histories, clinical photographs, study casts, periapical and panogram radiographs as well as a linear tomography or computerised tomography of the proposed implant sites.

The most important step in treatment planning is determining the prognosis for the dentition, and in particular prognosis for the tooth in question. Reasons for tooth extraction may include but are not limited to, insufficient crown to root ratios, remaining root length, periodontal attachment levels, status of furcations, periodontal health of teeth adjacent to the proposed implant site, unrestorable caries, root fractures with large endodontic posts, root resorption and questionable teeth in need of endodontic retreatment. ${ }^{32}$ Teeth requiring root amputations, hemisections or advanced periodontal procedures may have a questionable prognosis and patients should be given reasonable options before these procedures are implemented. Similarly, the option for implant placement for non vital teeth, fractured at the gingival margin with roots shorter than 13 $\mathrm{mm}$ should be considered as the treatment of choice. ${ }^{33}$ If treated using traditional methods, these teeth will require crown lengthening procedures, endodontic treatment, and posts and crowns. Removal of three or more millimetres of periodontal attachment during crown lengthening results in root length with less than optimal attachment. These factors are critical when teeth are being considered for abutments for fixed partial dentures. The risk to cost benefit ratio must also be considered.

In the aesthetic zone bone morphology, scallop of the periodontium, level of crestal and interproximal bone, smile line, morphology of the gingival tissues must be considered before initiating treatment. ${ }^{34-37}$ Proposed interimplant distance as well as existing contact relationships and interproximal bone must be analysed prior to implant placement. ${ }^{38-40}$ Patients with a thin or moderately thin periodontium will have soft tissue recession at the implanted sites. In these situations it is advisable to use orthodontic forced eruption procedures prior to tooth removal and implantation. This allows bone and soft tissues to move coronally, thereby assuring adequate mucosal tissue adjacent to the implant. Where there is a soft tissue deficiency subepithelial connective tissue grafting can further augment tissue height and thickness, thereby enhancing the aesthetic results. ${ }^{41,42}$ This procedure compensates for the slight soft tissue recession which usually occurs after tooth extraction.

Radiographic evaluation should consider availability of native bone, bone shape, quality, quantity, bone width and height. A minimum of 4-5 mm of bone width at the crest and $10 \mathrm{~mm}$ or greater from the alveolar crest to a safe distance above the mandibular canal is recommended. ${ }^{43}$ Sufficient distance must be available coronal to the maxillary sinus and floor of nose. For a satisfactory aesthetic result in the aesthetic zone, the interproximal bone height should be $5 \mathrm{~mm}$ or less when measured from the contact point of the adjacent tooth. As the distance from the contact point to the interproximal bone increases, the likelihood of retention of the interproximal papillae post implant placement diminishes. Patients must be made aware of potential aesthetic short-comings if implants are placed in jeopardised aesthetic zone sites.

Once the decision has been confirmed that the patient is a candidate for immediate implant placement, a surgical guide should be used to assure proper implant placement. A provisional appliance with an ovate pontic should be available for insertion after implant placement. ${ }^{44-50}$ 


\section{Tooth extraction and implant placement procedure}

The patient is anaesthetised and various flap procedures can be used to gain access for tooth extraction. ${ }^{51}$ Figures 1 to 11 represent the authors' routine surgical sequence for placement of a single tooth in the aesthetic zone after immediate implant placement using a minimally invasive method. Infection was present as evidenced by the purulent exudate exuding from the palatal aspects. Many clinicians postpone treatment of sites exhibiting infection. Villa recently reported on a case series of patients where implants were installed immediately after extraction. ${ }^{52}$ The extracted teeth exhibited signs of periodontal or endodontic infections. At two years the cumulative survival rate was $100 \%$. The results of this study indicate that once the infected teeth were removed and implants placed, there are no adverse results for the implanted sites. Teeth to be removed and implants placed immediately after extraction can be accessed using either an open, flapped approach or with a minimally invasive technique. With experience the surgeon can displace the marginal tissues buccal/lingually to gain access to the surgical site (Fig. 5). A Molt C2 (Hufriedy, Chicago) curette can be used to luxate the root mesial-distally. Care must be exercised not to luxate buccal-lingually. Excessive force in this direction can damage the buccal plate. After tooth removal, a curette is used to explore the location of the buccal plate and confirm that it is intact. The surgical guide is placed over the surgical site and a sharp Precison Drill (Nobel Biocare, Precision Drill, Yorba Linda, California) is used to penetrate the palatal wall of the extraction socket (Fig. 7). ${ }^{11}$ This drill guides the drills used to create the osteotomy. In the maxillary anterior region it is important to avoid placing the implant directly into the extraction socket. Placement of the implant in this position will invariably cause the implant to perforate the buccal plate and jeopardise implant survival. The axis of the implant must be even with the incisal edges of the adjacent teeth or slightly palatal to this landmark. A direction indicator should be used to verify the correct angulation and trajectory of the proposed implant (Fig. 8). Standard drilling procedures are performed according to the manufacturers' instructions. In the aesthetic zone, the implant head should be a minimum of $3 \mathrm{~mm}$ apical to an imaginary line connecting the cemento-enamel junctions of the adjacent teeth and apical to the interproximal and crestal bone. ${ }^{53}$ A healing abutment or cover screw is placed in the implant. The healing abutment should be even with or slightly apical to the adjacent marginal tissues. Interproximal papillae adjacent to the implant can be adapted with interrupted sutures under minimal tension. The provisional is then inserted, and evaluated, making certain the pontic is clear of the healing abutment. The provisional restoration should have an ovate pontic to support the adjacent tissues and help preserve soft tissue anatomy

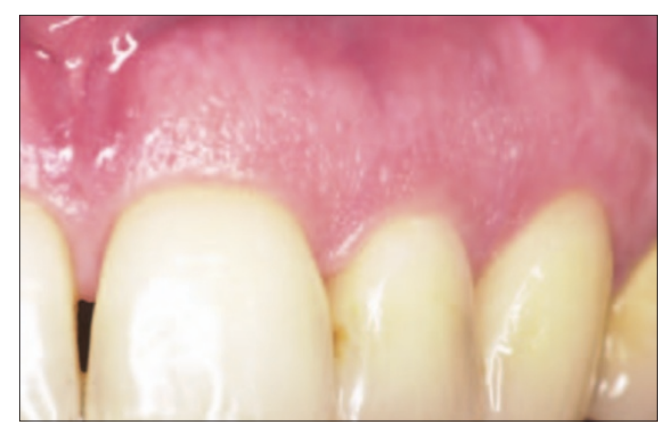

Fig. 1 The maxillary left lateral incisor has a blunted short root with a severe palatal infection related to a non-vital tooth

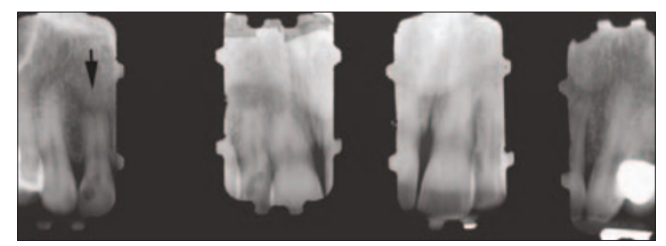

Fig. 2 Left maxillary lateral incisor (arrow) has a blunted apex, possible coronal fracture and a draining abscess

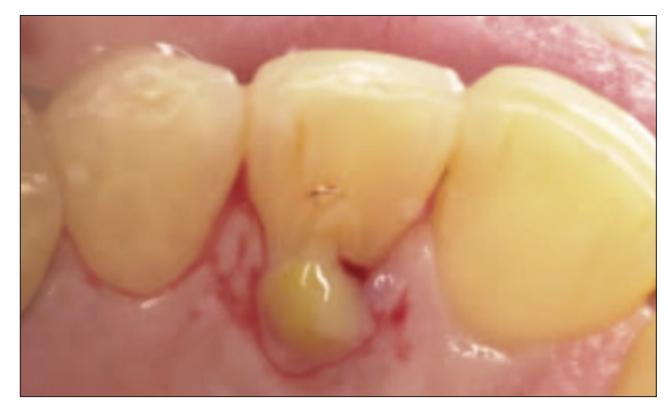

Fig. 3 Supparation expressed from palatal aspect of maxillary left lateral incisor

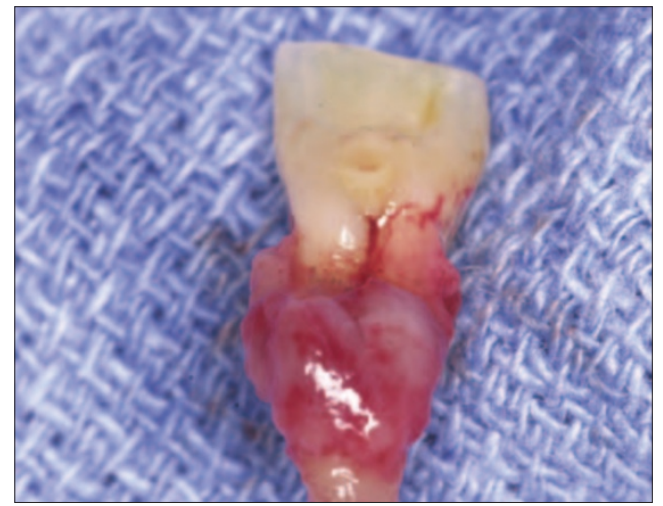

Fig. 4 Extensive palatal granulation tissue

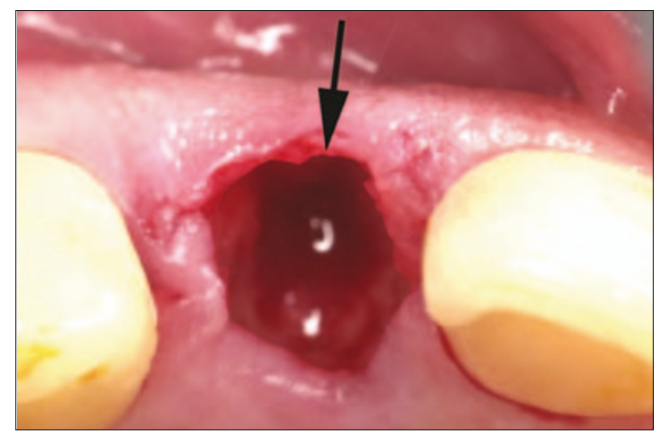

Fig. 5 Tooth has been extracted. Arrow points to socket

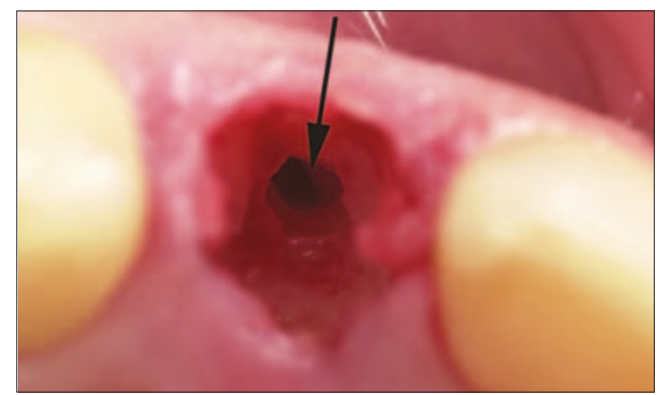

Fig. 6 Osteotomy has been prepared in palatal aspect of extraction socket 
Fig. 7 Guide pin within palatal aspect of surgical guide

Fig. 8 Implant has been inserted into osteotomy and a $4 \mathrm{~mm}$ healing abutment has been placed onto the implant. Arrow points to gap between mucosal tissue and healing abutment

Fig. 9 Bovine bone has been layered into gap between mucosal tissue and abutment (arrow)

Fig. 10 Tissues sutured with no attempt to advance flap over bovine bone particles

Fig. 11 Two year follow-up photograph. Note how interdental papillae fill entire embrasure spaces. There is slight soft tissue inflammation between lateral and canine
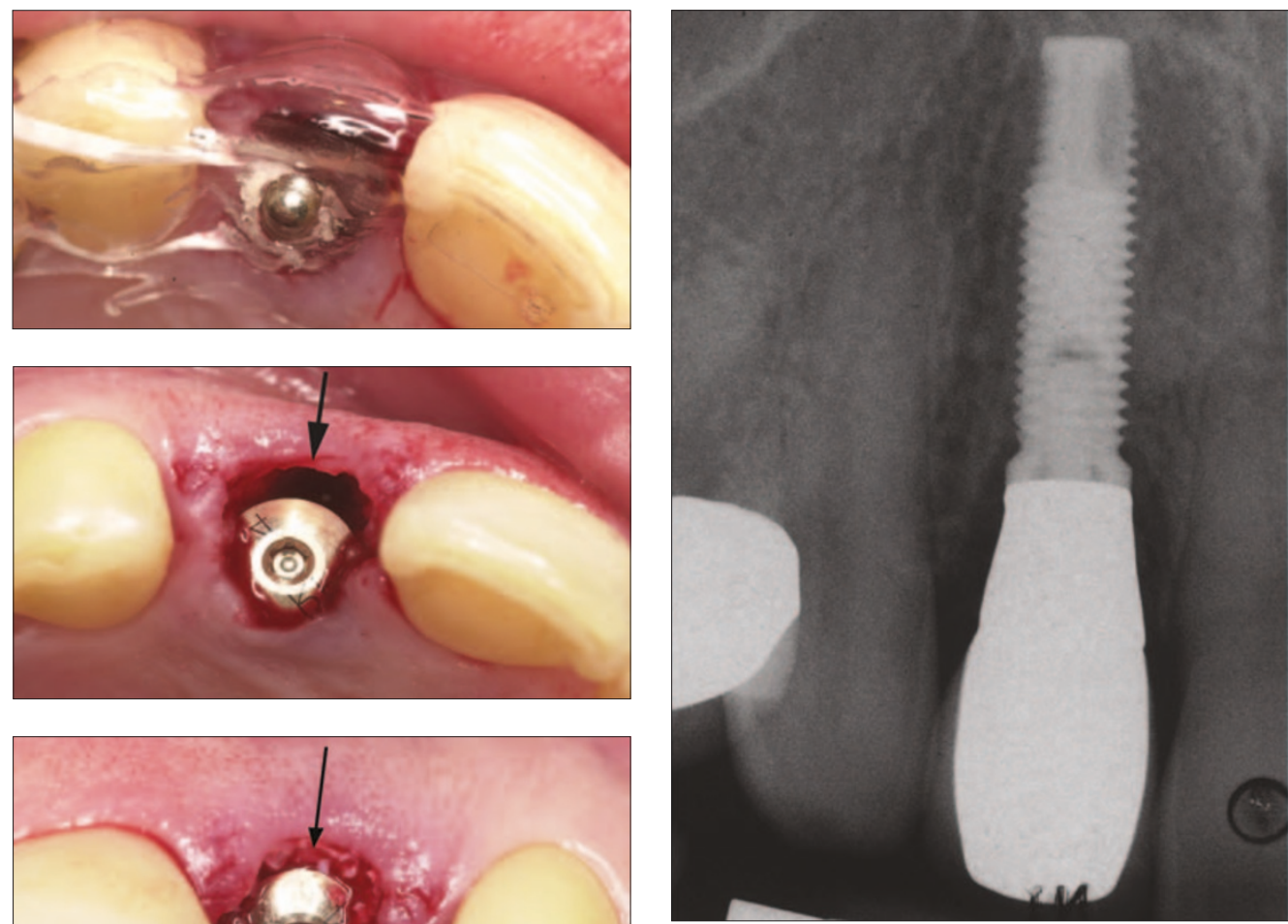

Fig. 12 Two year follow up radiograph. Note stabile interproximal bone

\section{The gap}

On occasion the marginal tissues do not adapt to the healing abutment. In experimental studies, if the gap is too wide, connective tissue forms between the coronal implant aspect and surrounding bone. ${ }^{54,55}$ A series of animal and human studies has demonstrated that small gaps between implants and bone will fill with bone with or without grafting materials or barriers. ${ }^{56-61}$ Botticelli et al. created 1.0-2.5 mm wide circumferential defects in dogs. At a few sites, the labial bone adjacent to the socket was reduced. Over a four month healing period the circumferential defects healed with bone. At sites where the labial bone was reduced, proper bone healing occurred at the mesial, distal and lingual defect aspects, but reduced bone volume occurred on the labial surface. The same authors repeated the study. Special implants were inserted into the defects, leaving a 1.0-2.5 mm gap between the implants and surrounding bone. Bovine bone alone or with a resorbable barrier was used to augment some sites, while others were left to spontaneously heal. It was demonstrated that at four months, all defects filled with newly formed bone and the biomaterial placed in the marginal defect in conjunction with implant installation became incorporated in newly formed bone tissue. A high degree of contact was established between the bovine bone particles and the newly formed bone. In the model used, bovine bone did not enhance the process of bone formation and defect closure. Recently a prospective trial was reported using various augmentation techniques at immediate implant sites. ${ }^{62}$ The efficacy of combinations of membranes and autogenous bone grafts at immediate implants were compared. Sixty-two 
consecutively treated patients each received an immediate implant for a single tooth replacement at a maxillary anterior or premolar site. Dimensions of the peri-implant defect at the implant collar were measured as follows: vertical defect height (VDH), horizontal defect depth (HDD) and horizontal defect width (HDW). Each implant randomly received one of five augmentation treatments and was submerged with connective tissue grafts: Group 1 expanded polytetrafluoroethylene membrane only, Group 2 resorbable polylactide/polyglycolide copolymer membrane only, Group 3 resorbable membrane and autogenous bone graft; Group 4 autogenous bone graft only, and Group 5 no membrane and no bone graft control. At re-entry, all groups showed significant reduction in VDH, HDD and HDW. Comparisons between groups showed no significant differences for VDH (mean 75.4\%) and HDD (mean 77\%) reduction. Significant differences were observed between groups for HDW reduction (range, 34.1-67.3\%), with membrane-treated Groups 1, 2 and 3 showing the greatest reduction. In the presence of dehiscence defects of the labial plate, HDW reduction of $66.6 \%$ was achieved with membrane use compared with $37.7 \%$ without membranes. Over 50\% more labial plate resorption occurred in the presence of a dehiscence defect irrespective of the augmentation treatment used. The results indicate that VDH and HDD reduction at defects adjacent to immediate implants may be achieved without the use of membranes and/or bone grafts.

In practice, when the gap is present no effort is made to surgically advance the flap (Fig. 8). A small amount of allograft or alloplast is layered between the margin and implant abutment (Fig. 9). This material is left exposed. Within a few weeks some of the material will be exfoliated and gingival mucosa will migrate over the exposed materials and healing is uneventful.

Bovine bone has been used to augment small gaps adjacent to immediately placed implants. ${ }^{63,64}$ Results from these studies demonstrate that the bovine bone does not affect the survival of implants. It is important to recognise that placement of bovine bone, allografts or other substances with or without barrier membranes may support or improve soft tissue contours; however, these materials cannot be relied upon to enhance osseointegration.

\section{Socket preservation}

Socket preservation is a relatively new term to implant dentistry. It implies that placement of varying implantable materials within the sockets alone or with barrier membranes maintains socket anatomy. To date, there is inconclusive evidence this procedure maintains original socket dimensions. There is some evidence that placement of foreign materials into extraction sockets will interfere with normal bone formation. ${ }^{65,66}$ Iasella et al. compared normal socket healing with those grafted with demineralised freeze dried bone and covered with a collagen barrier membrane. ${ }^{67}$ Unaugmented or grafted sockets decreased in width by an average of 1.7 $\mathrm{mm}$, while grafted sites decreased by $1.2 \mathrm{~mm}$ (difference of $0.5 \mathrm{~mm}$ ). The quantity of bone observed on histologic analysis was slightly greater in preservation sites, although these sites included both vital and non-vital bone. Others compared ridge dimensions and histologic characteristics of ridges preserved with two different graft materials. ${ }^{68}$ Twenty-four subjects, each requiring a nonmolar extraction and delayed implant placement, were randomly selected to receive ridge preservation treatment with either an allograft in an experimental putty carrier plus a calcium sulphate barrier or a bovine-derived xenograft plus a collagen membrane. Horizontal and vertical ridge dimensions were determined using a digital caliper and a template. At four months postextraction, a trephine core was obtained for histologic analysis. Allograft mixed with an experimental putty carrier produced significantly more vital bone fill than did the use of a xenograft with no carrier material. Ridge width and height dimensions were similarly preserved with both graft materials. Placement of materials into extraction sockets might be termed osseointerference.

There is evidence that resorbable barriers without grafting reduces alveolar ridge resorption after tooth extraction. ${ }^{69}$ Following elevation of buccal and lingual full-thickness flaps and extraction of teeth, experimental sites were covered with bioabsorbable membranes; control sites did not receive barrier membranes. Titanium pins served as fixed reference points for measurements. Flaps were advanced in order to achieve primary closure of the surgical wound. There was no membrane exposure during the course of healing. Reentry surgeries were performed at six months. Results showed that experimental sites presented with significantly less loss of alveolar bone height, more internal socket bone fill, and less horizontal resorption of the alveolar bone ridge. This study suggests that treatment of extraction sockets with membranes made of glycolide and lactide polymers is valuable in preserving alveolar bone in extraction sockets and preventing alveolar ridge defects. Use of these materials may minimise crestal resorption, and may be indicated to minimise ridge resorption if dental implants are not part of the treatment plan. Placement of implants into these materials may limit osseointegration. Until there is sufficient evidence that these materials maintain socket anatomy, and do not interfere with osseointegration, caution should be exercised.

\section{CONCLUSION}

The purpose of this paper was to review the history, predictability, rationale and treatment planning steps for implant placement immediately after tooth extraction. Multi-centre studies have validated the predictability of placing implants at the time of extraction provided these procedures are appropriately treatment planned. 
5,7,8,11,30,70,71 To date, evidence for placement of bone substitutes adjacent to small bone defects related to immediately placed implants appears safe, although these materials do not appear to predictably promote osseointegration. There is insufficient evidence that 'socket preservation' procedures predictably maintain socket anatomy without crestal resorption. Bone substitutes implanted into extraction sockets may interfere with normal bone healing and ultimately osseointegration. A minimally invasive approach offers several patient advantages and should be employed wherever possible.

1. Branemark PI et al. Osseointegrated implants in the treatment of the edentulous jaw. Experience from a 10-yea period. Scand J Plast Reconstr Surg Supp/ 1977; 16: 1-132.

2. Adell $R$ et al. Long-term follow-up study of osseointegrated implants in the treatment of totally edentulous jaws. Int J Oral Maxillofac Implants 1990; 5: 347-349.

3. Adell R, Lekhholm, Branemark PI. A 15-year study of osseointegrated implants in the treatment of the edentulous jaw. Int J Oral Surg 1985; 10: 387-418.

4. Lazzara R J. Immediate implant placement into extraction sites: surgical and restorative advantages. Int J Periodont Rest Dent 1989; 9: 332-343.

5. Becker W et al. The use of e-PTFE barrier membranes for bone promotion around titanium implants placed into extraction sockets: a prospective multicenter study. Int J Oral Maxillofac Implants 1994; 9: 31-40.

6. Becker W et al. Five-year evaluation of implants placed at extraction and with dehiscences and fenestration defects augmented with ePTFE membranes: results from a prospective multicenter study. Clin Implant Dent Relat Res 1999; 1: 27-32

7. Gelb D A. Immediate implant surgery: three-year retrospective evaluation of 50 consecutive cases. Int J Oral Maxillofac Implants 1993; 8: 388-399.

8. Grunder U etal. A 3-year multicenter follow-up report on the immediate and delayed-immediate placement of implants. Int J Oral Maxillofac Implants 1999; 14: 210-216.

9. Rosenquist $\mathrm{B}$, Ahmed $\mathrm{M}$. The immediate replacement of teeth by dental implants using homologous bone membranes to seal the sockets: clinical and radiographic findings. Clin Oral Implants Res 2000; 11: 572-582.

10. Schwartz-Arad D, Chaushu G. Immediate implant placement: a procedure without incisions. J Periodontol 1998; 69: 743-750.

11. Becker et al. Autogenous bone grafting of bone defects adjacent to implants placed into immediate extraction sockets in patient: A prospective study. Int J Oral Maxillofac Implants 1994; 9: 389-396.

12. ten Bruggenkate $C M$ et al. Autogenous maxillary bone grafts in conjunction with placement of ITI endosseous implants. AS preliminary report. Int J Oral Maxillofac Surg 1996: 21: 81-84

13. Nevins M, Mellonig J T. Enhancement of the damaged edentulous ridge to receive dental implants: a combination of allograft and the GORE-TEX membrane. Int J Periodont Rest Dent 1992; 12: 96-111.

14. Mellonig J T, Triplett R G. Guided tissue regeneration and endosseous dental implants. Int J Periodont Rest Dent 1993; 13: 109-119.

15. Nevins M, Mellonig J T. The advantages of localized ridge augmentation prior to implant placement: a staged event. Int J Periodont Rest Dent 1994; 14: 96-111.

16. Mellonig J T, Nevins M. Guided bone regeneration of bone defects associated with implants: an evidence-based outcome assessment. Int J Periodont Rest Dent 1995; 15: 168-185.

17. Buser D et al. Osseointegration of titanium implants in bone regenerated in membrane-protected defects: a histological study in the canine mandible. Int J Oral Maxillofac Implants 1995; 10: 666-681.

18. Buser $\mathrm{D}$ et al. Localized ridge augmentation using guided bone regeneration. II. Surgical procedure in the mandible. Int J Periodont Rest Dent 1995: 15: 10-29.

19. Buser $D$ et al. Lateral ridge augmentation using autografts and barrier membranes: a clinical study with 40 partially edentulous patients. J Oral Maxillofac Surg 1996; 54: 420-432.
20. Buser D et al. Long-term stability of osseointegrated implants in bone regenerated with the membrane technique. 5-year results of a prospective study with 12 implants. Clin Oral Implants Res 1996; 7: 175-183.

21. Gotfredsen K et al. Evaluation of guided bone generation around implants placed into fresh extraction sockets: an experimental study in dogs. J Oral Maxillofac Surg 1993; 51:879-884.

22. Buser $D$ et al. Regeneration and enlargement of jaw bone using guided regeneration. Clin Oral Implants Res 1990; 1: 22-32.

23. Hermann J S, Buser D. Guided bone regeneration for dental implants. Curr Opin Periodont 1996; 3: 168-177.

24. Meredith N D, Alleyne, Cawley P. Quantitative determination of the stability of the implant-tissue interface using resonance frequency analysis. Clin Oral Implants Res 1996; 7: 261-267.

25. Meredith $\mathrm{N}$ et al. Resonance frequency measurements of implant stability in vivo. A cross-sectional and longitudinal study of resonance frequency measurements on implants in the edentulous and partially dentate maxilla. Clin Oral Implants Res 1997; 8: 226-233.

26. Sennerby L, Meredith N. Resonance frequency analysis: measuring implant stability and osseointegration. Compend Contin Educ Dent 1998; 19: 493-498, 500, 502, quiz 504.

27. Rasmusson L etal. Stability assessments and histology of titanium implants placed simultaneously with autogenous onlay bone in the rabbit tibia. Int J Oral Maxillofac Surg 1998; 27: 229-235.

28. Rasmusson $L$ et al. Effects of barrier membranes on bone resorption and implant stability in onlay bone grafts. An experimental study. Clin Oral Implants Res 1999; 10: $267-277$.

29. Sennerby L et al. A comparison of implant stability in mandibular and maxillary bone using RFA. In Meredith L S L (Ed). European Commission Demonstration Project: Resonance Frequency Analysis Symposium. pp 1-12. Gothenburg, Sweden: Vasastadens Bokbinderi AB, 2000.

30. Becker W, Sennerby L, Bedrossian E, Becker B E, Lucchini J P. Implant stability measurements for implants placed at the time of extraction: a cohort, prospective clinical trial. J Periodontol 2005; 76: 391-397.

31. Nir-Hadar O, Palmer M, Soskolne W A. Delayed immediate implants: alveolar bone changes during the healing period [in process citation]. Clin Oral Implants Res 1998; 9: 26-33.

32. Becker W, Becker B E, Hujoel P. Retrospective case series analysis of the factors determining immediate implant placement. Compend Contin Educ Dent 2000; 21 : 805-808, 810-811, 814 passim, quiz 820.

33. Lovdahl P. Endodontic retreatment. Dent Clin North Am 1992; 36: 473-490.

34. Ochsenbein $C, 0$ chsenbein R S. A reevaluation of osseous surgery. pp 87-102. 1969

35. Becker W et al. Alveolar bone anatomic profiles as measured from dry skulls. Clinical ramifications. J Clin Periodonto 1997; 24: 727-731.

36. Kois J C. Predictable single tooth peri-implant esthetics: five diagnostic keys. Compend Contin Educ Dent 2004; 25: 895-905, quiz 905.

37. Kan J Y, Rungcharassaeng K, Umezu K, Kois J C. Dimensions of peri-implant mucosa: an evaluation of maxillary anterior single implants in humans. J Periodonto/ 2003; 74: 557-562.

38. Tarnow $D$ etal Vertical distance from the crest of bone to the height of the interproximal papilla between adjacent implants. J Periodonto/ 2003; 74: 1785-1788.

39. Tarnow D P, Magner A W, Fletcher P. The effect of the distance from the contact point to the crest of bone on the presence or absence of the interproximal dental papilla. J Periodont 1992; 63: 995-996.

40. Stahl S S, Froum S, Tarnow D. Human histologic responses to guided tissue regenerative techniques in intrabony lesions. Case reports on nine sites. J Clin Periodont 1990; 17: 191-198.

41. Langer B. The esthetic management of dental implants. Dent Econ 1995; 85: 86-87.

42. Langer $B$. The regeneration of soft tissue and bone around implants with and without membranes. Compend Contin Educ Dent 1996; 17: 268-270, 272 passim, quiz 280.

43. Worthington P. Injury to the inferior alveolar nerve during implant placement: a formula for protection of the patient and clinician. Int J Oral Maxillofac Implants 2004; 19: 731-734.

44. Berman F. The creation of an ovate pontic at the time of extraction. Dent Today2003; 22: 48-49. 
45. Dylina T J. Contour determination for ovate pontics. J Prosthet Dent 1999; 82: 136-142.

46. Johnson $G$ K, Leary J M. Pontic design and localized ridge augmentation in fixed partial denture design. Dent Clin North Am 1992; 36: 591-605.

47. Levine R A, Makrauer Z. The use of periodontal plastic surgery procedures in aiding esthetic restorative results. Compend Contin Educ Dent 2003; 24: 729-734, 738 passim, quiz 741.

48. Miller M B. Aesthetic anterior reconstruction using a combined periodontal/restorative approach. Prac Periodont Aest Dent 1993; 5: 33-40, quiz 42.

49. Miller M B. Ovate pontics: the natural tooth replacement. Prac Periodont Aest Dent 1996; 8: 140.

50. Zitzmann N U, Marinello C P, Berglundh T. The ovate pontic design: a histologic observation in humans. J Prosthet Dent 2002: 88: 375-380.

51. Becker W, Becker B E. Flap designs for minimization of recession adjacent to maxillary anterior implant sites: a clinical study. Int J Oral Maxillofac Implants 1996; 11: 46-54.

52. Villa R, Rangert B. Early loading of inerforaminal implants immediately installed after extraction of teeth presenting endodontic and periodontal lesions. Clin Imp Dent and Related Res 2005; 7: S28-S35.

53. Langer B, Sullivan D Y. Osseointegration: its impact on the interrelationship of periodontics and restorative dentistry. Part 3. Periodontal prosthesis redefined. Int J Periodont Rest Dent 1989; 9: 240-261.

54. Carlsson L et al. Implant fixation improved by close fit. Cylindrical implant-bone interface studied in rabbits. Acta Orthop Scand 1988; 59: 272-275.

55. Akimoto $\mathrm{K}$ et al. Formation of bone around titanium implants placed into zero wall defects: pilot project using reinforced e-PTFE membrane and autogenous bone grafts. Clin Implant Dent Relat Res 1999; 1: 98-104.

56. Scipioni A et al. Healing at implants with and without primary bone contact. An experimental study in dogs. Clin Oral Implants Res 1997; 8: 39-47.

57. Botticelli D et al. The jumping distance revisited: An experimental study in the dog. Clin Oral Implants Res 2003 14:35-42.

58. Botticelli $D$ et al. Appositional bone formation in marginal defects at implants. Clin Oral Implants Res 2003; 14: 1-9.

59. Botticelli D, Berglundh T, Lindhe J. Hard-tissue alterations following immediate implant placement in extraction sites. J Clin Periodontal 2004; 31: 820-828.

60. Botticelli D T, Berglundh, Lindhe J. The influence of a biomaterial on the closure of a marginal hard tissue defect adjacent to implants. An experimental study in the dog. Clin Oral Implants Res 2004; 15: 285-292.

61. Botticelli D T, Berglundh, Lindhe J. Resolution of bone defects of varying dimension and configuration in the marginal portion of the peri-implant bone. An experimental study in the dog. J Clin Periodonto/ 2004; 31: 309-317.

62. Chen ST et al. A prospective clinical study of bone augmentation techniques at immediate implants. Clin Oral Implants Res 2005; 16: 176-184.

63. van Steenberghe $D$ et al. The clinical use of deproteinized bovine bone material on bone regeneration in conjunction with immediate implant installation. Clin Oral Implants Res 2000; 11: 210-216

64. Zitzmann N U, Naef R, Scharer P. Resorbable versus nonresorbable membranes in combination with Bio-Oss for guided bone regeneration [published erratum appears in Int J Oral Maxillofac Implants 1998; 13: 576]. Int J Oral Maxillofac Implants 1997; 12: 844-852.

65. Becker W, Becker B E, Caffesse R. A comparison of demineralized free-dried bone and autologous bone to induce bone formation in human extraction sockets [published erratum appears in J Periodonto/ 1995; 66: 309 - see comments]. J Periodontol 1994; 65: 1128-1133.

66. Becker $W$ et al. Histologic findings after implantation and evaluation of different grafting materials and titanium micro screws into extraction sockets: case reports. J Periodontol 1998; 69: 414-421.

67. lasella J M et al. Ridge preservation with freeze-dried bone allograft and a collagen membrane compared to extraction alone for implant site development: a clinical and histologic study in humans. J Periodonto/2003; 74: 990-999.

68. Vance $G S$ etal. Comparison of an allograft in an experimental putty carrier and a bovine-derived xenograft used in ridge preservation: a clinical and histologic study in humans. Int J Oral Maxillofac Implants 2004; 19: 491-497.

69. Lekovic $V$ et al. Preservation of alveolar bone in extraction sockets using bioabsorbable membranes. J Periodontol 1998; 69: 1044-1099.

70. Berg L, Becker W, Becker B E. The use of index teeth to predict the health status of the balance of the mouth. Int J Periodont Rest Dent 1984; 4: 46-54.

71. Gotfredsen K, Nimb L, Hjorting-Hansen E. Immediate implant placement using a biodegradable barrier, polydroxybutyrate-hydroxyvalerate reinforced with polyglactin 910. An experimental study in dogs. Clin Oral Implants Res 1994; 5: 83-91. 